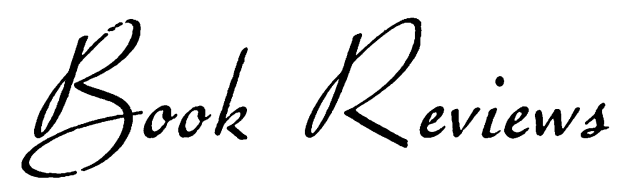

\section{A SYNOPSIS OF SURGICAL ANATOMY}

By Alexander LeE McGregor, M.Ch., F.R.C.S. 8th edition. Pp. xii +808 , with 766 diagrams. Bristol : John Wright \& Sons Ltd. 1957. 32s. 6d.

'Lee McGregor' has stood the test of time and, no doubt, will continue so to do. This new eighth edition continues in the excellence of its predecessors; some of the older text has been omitted to make way for new work. The sections devoted to the anatomy and surgery of the autonomic $n \in$ rvous system have been rewritten and the coverage extended; sections of the paragangliomata, adrenalectomy and injuries to large lymph ducts have been included.

The new section on the herniae of the diaphragm must be singled out for praise, the text and illustrations settling much turbulence of thought on these matters. Although this chapter, together with those on the anal sphincters and their disease relations and that on the autonomies, are worthy of special mention, the rest of the text maintains its very high standard of presentation and comprehension, aided by the excellent illustrations of Dr. E. A. Thomas, to produce a 'Synopsis' whose value to the practising surgeon and instructing anatomist is supreme.

\section{EXTENSILE EXPOSURE}

By Arnold K. Henry, M.B., M.Ch., F.R.C.S.I. 2nd edition. Pp. xii +320 , with 298 illustrations. Edinburgh: E. \& S. Livingstone Ltd. 1957. 45 s.

It is a delight to see another edition of Professor Henry's book, which must be part of every surgeon's reading for two reasons, firstly for its content and secondly for its presentation. It is hardly likely to be paralleled anywhere in scientific writing as a prime example of the use of the English language and its literature to present cold fact with such warmth and life.

The first text has been extended to include approaches in the neck to Burn's space, virtually the entire length of the vertebral artery and special exposures for operative treatment of torticollis. Section II now describes a posterior approach to the first part of the subclavian artery, a new variety of aneurysm needle-most adept, a technique for removing pulmonary emboli and an anterior extrapleural approach to the sympathetic chain. The problem of bleeding at prostatectomy receives attentior in Section III, with an extraperitoneal method of ' prelusive ' ligation of arteries ' named 'prostatic before prostatectomy; the same approach is described for section of the sensory nerve to the hip joint.

In these times of rapidly extending surgical treatment of major limb arteries, Section IV is particularly welcome in that the previously described approaches are supplemented by a series of exposure methods for the deeper branches of the femoral artery, both from in front and behind, and approaches to the distal part and branches of the popliteal artery. To this vascular part is added an account of a technique for removing the talus.

The publishers produce a volume up to theio usual standard of excellence, particularly notable in this instance for its truly ' handy' size. Altogetheg this book deserves the highest praise on all account and in particular, as noted above, for its literare example, which could be followed with advantage ${ }^{+}$ by such a large majority of current authors.

\section{PHYSICAL METHODS IN PHYSIOLOGY}

By W. T. Catton, M.Sc. Pp. xi +375 , illustrated. London: Sir Isaac Pitman \& Sons Ltd. 1957. $42 s$.

This book is a welcome addition to the still sparse literature of biophysics. In each of the six main chapters the physical methods which have been used in the study of a particular physiological system are described and the results achieved are discussed. The chapter headings are 'Blood,' 'Circulation,' 'Respiration,' 'Muscle,' 'Peripheral Nerve' and 'The Physical Basis of Body Heat Exchanges.' There is a final chapter on the difficulties of applying electronic techniques to biology. Special senses, the E.C.G. and E.E.G. are deliberately excluded as being well served a!ready by special treatises.

The author has given a very thorough account, in this limited field, of the achievements of physical technique and all workers in experimental physiology and medicine might find it valuable as a source of reference. It is not, however, easy reading. The author expects a fair knowledge of physics in the reader (for instance, entropy appears without 
explanation) and mathematics is not excluded. Nevertheless, the serious student of experimental biology, prepared to consult other works in parallel, will not regret the effort.

\section{GENERAL UROLOGY}

By D. R. Sмiтh, M.D. Pp. 326, illustrated. Los Altos: Lange Medical Publications. I 957. $\$ 4.50$.

This is an American book printed so as to resemble typescript. The author states in his preface that the book is written for the medical student and general practitioner not specializing in urology. It is questionable as to how many readers of these categories in this country will wish to read a fairly long monograph on urology, much of the material being covered in textbooks of general surgery.

Those who do read it will, however, be well rewarded, as it is an excellent book within its selfimposed limitations, giving a very rational, complete and well-balanced account of urological pathology, symptomatology and methods of investigation. Methods of treatment, particularly when these are surgical, are covered less adequately, befitting the aim of the book.

\section{OPERATIVE SURGERY}

\section{Volume III-Rectum and Anus. Thorax}

Edited by Charles Robb, M.C., M.Chir., F.R.C.S., and Rodney Smith, M.S., F.R.C.S. Pp. xii + 2 I 5, illustrated. London: Butterworth \& Co. Ltd. I957. £5 ros.

This volume continues the very high standard of its predecessors in both subject matter and style of presentation. It contains Parts IV and $\mathrm{V}$ of the complete work, the former dealing with rectal surgery and the latter with thoracic surgery. The staff of St. Mark's Hospital have for several generations enjoyed a world-wide reputation for the lucid teaching of the practice of rectal surgery and LloydDavies, Lockhart-Mummery and Professor Goligher (lately at St. Mark's) give fresh support to this tradition in their admirable chapters. The contributions by the other three authors to this part are equally valuable.

The sections dealing with thoracic surgery are written by a larger number of authors, but the standard is also uniformly high. The section on cardiac arrest is refreshingly simple and should be read by surgeons who operate on any part of the body. There would seem to be a good case for incorporating this section in the first volume dealing with surgical technique.

This volume confirms the impression left after reading the first two volumes that the complete work will be the standard reference on operative surgery for norny years to come.

\section{AN ATLAS OF MUSCLE PATHOLOGY IN NEUROMUSCULAR DISEASES}

By J. Godwin Greenfield, M.D., G. Milton Shy, M.D., Ellsworth C. Alvord, JR., M.D., and LeONARD Berg, M.D. Pp. ix + I04, with 93 illustrations, many in colour. Edinburgh: E. \& S. Livingstone Ltd. 1957. 45 s.

The illustrations in this book are very good. But it is not just an atlas; it is a genuine piece of original work. Everyone interested in the histology and pathology of muscle will find it indispensable.

D.M.P.

\section{PULMONARY EMPHYSEMA}

Edited by A. L. Barach, M.D., and H. A. Bickerman, M.D. Pp. $\mathrm{x}+545$, with $\mathrm{I} 85$ illustrations. London: Bailliere, Tindall \& Cox Ltd. 1956. 8os.

Physicians in this country would greatly appreciate a clear, concise and authoritative review of the problem of pulmonary emphysema and bronchitis. Under the editorship of Professor A. L. Barach and Dr. H. A. Bickerman I 8 experienced investigators in this field have combined to produce a textbook which aims to fill this need. That this effort has not been entirely successful should not obscure the fact that this book is probably the best available source of up-to-date information on emphysema. The problem is approached in a contemporary manner with proper emphasis upon the pathological physiology of the bronchi, lung parenchyma and skeletal structures. The role of infections is inadequately discussed as far as British needs are concerned, but possibly infection is of less importance in the United States. A further difference is the use of intermittent positive pressure breathing and ' exsufflation,' combined with aerosol therapy, for the treatment of acute and chronic respiratory failure. In this country greater use would be made of tracheotomy (not mentioned), combined with mechanical respirators, either with or without a negative pressure phase.

The metabolic aspects of acute and chronic respiratory failure are only briefly discussed and the recent work on the reaction between ${\mathrm{p} . \mathrm{Co}_{2}}_{2}$ and bicarbonate reabsorption by the kidneys is not mentioned. Nevertheless, the book contains a great amount of valuable information and no doubt will be widely read by those interested in the care of patients with emphysema.

\section{MATERIA MEDICA AND PHARMACOLOGY FOR NURSES}

By J. S. Peel, M.P.S. Second edition. Pp. I72, with I4 diagrams. Christchurch, New Zealand: N. M. Peryer Limited. 1957. 24s.

A second edition of this well-known book is most welcome, presenting the most up-to-date text for student nurses. 